\section{ECONOMICS}

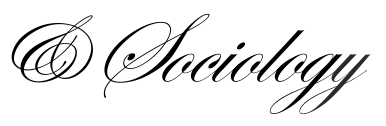

Widarjono, A. (2020). Asymmetric Okun's law in an emerging market: ASEAN-3 case. Economics and Sociology, 13(3), 203-217. doi:10.14254/2071789X.2020/13-3/12

\title{
ASYMMETRIC OKUN'S LAW IN AN EMERGING MARKET: ASEAN-3 CASE
}

\author{
Agus Widarjono \\ Department of Economics, \\ Faculty of Business and Economics, \\ Universitas Islam Indonesia, \\ Yogyakarta, Indonesia \\ E-mail: \\ agus.widarjono@uii.ac.id
}

Received: October, 2019

1st Revision: April, 2020

Accepted: September, 2020

DOI: $10.14254 / 2071-$

789X.2020/13-3/12

\begin{abstract}
This study examines the force of the asymmetric Okun's law in Malaysia, the Philippines, and Singapore (the ASEAN-3). We employ the cointegration test using the nonlinear autoregressive distributed lag (NARDL) and the asymmetric Pooled Mean Group (PMG) model. Our findings conclude that the cointegration between unemployment and output is found, and the asymmetric Okun's law exists in all the countries under consideration. This suggests that economic upturn and downturn have different impacts on the unemployment in the ASEAN-3. More importantly, economic downturns have a larger impact on unemployment than economic booms. However, positive or negative long-run asymmetric Okun varies across the countries. The Philippines created more jobs during an economic upturn and Singapore lost more jobs during an economic downturn than other countries. The asymmetric PMG confirms that rising and falling domestic output has a significant impact on unemployment. The asymmetric panel also proves that economic downturns have a stronger impact on unemployment than economic upturns in the ASEAN-3.
\end{abstract}

JEL Classification: C22, C23, E32, J64
Keywords: Okun's law, NARDL, asymmetric panel cointegration, ASEAN-3.

\section{Introduction}

The question about the unemployment-output tradeoff was originally raised by Okun. This theory initially explained the negative relationship between unemployment and output in the US in which GDP will be decreasing by approximately $3 \%$ as compared to its potential GDP when the unemployment rate increases by $1 \%$. The unemployment-output tradeoff has been intensively investigated in empirical studies. Many of them were initially carried out to test the Okun's theory in developed countries. Notable among them are Weber (1997), Silvapulle, Moossa, and Silvapulle (2004), and Grant (2018) for the US; Hamada and Kurosaka (1984) for Japan; Lee (2000) for the OECD; Ball (2017) and Ball, Furceri, Leigh, and Loungani, (2019) for advanced economies overall. Several empirical studies have also been carried out for transition economies (Gabrisch \& Buscher, 2006; Cevik, Dibooglu, \& Barişik, 2013) and for developing countries (Durech, Minea, Mustea, \& Slusna, 2014; Ball, Furceri, Leigh, \& Loungani, 2019). 
Many empirical studies initially investigated the unemployment-output tradeoff that is assumed to be a symmetric relationship. The cyclical output symmetrically affects unemployment. Economic upturns and downturn may result in the same effects on the unemployment rate (Hamada \& Kurosaka, 1984; Attfield \& Silverstone, 1998; Lee, 2000; Christopoulus, 2004; Gabrisch \& Buscher, 2006). However, the symmetric unemploymentoutput tradeoff is questionable because the labor market responds to the business cycle in an asymmetric pattern (Perman \& Tavera, 2005; Beyaert \& García-Solanes, 2014). In dealing with this problem, empirical studies are increasingly switching their concern to the asymmetric relationship between unemployment-output (Harris \& Silverstone, 2001; Altissimo \& Violante, 2001; Marinkov \& Geldenhuys, 2007; Tang \& Bethencourt, 2017).

The Association of Southeast Asian Nations (ASEAN) is a regional intergovernmental organization among the Southeast Asian countries. The ASEAN agreed on their economic integration back in 1992. ASEAN, which now comprises ten countries, has a huge labor force and accordingly, is constantly facing unemployment problems. The total labor force of the ASEAN, as of 2018, was 329.817 million which accounted for $50.44 \%$ of the total population of 653.900 million. Some ASEAN members are emerging markets such as Malaysia, Indonesia, Singapore, Thailand, and Vietnam. Our study examines the asymmetric unemployment-output tradeoff in the selected Southeast Asian countries, namely, Malaysia, the Philippines, and Singapore (the so-called ASEAN-3).

New knowledge on the unemployment-output relationship within the ASEAN-3 may help policy-makers in formulating an appropriate economic policy regarding unemployment during economic upturns and downturns. However, the empirical studies on the asymmetric Okun's law in emerging markets such as ASEAN members are still rare. This paper contributes to the empirical research on the unemployment-output relationship in several ways. First, our study uses an asymmetric method employing nonlinear ARDL (NARDL) method to examine the unemployment-output tradeoff in the ASEAN-3. Second, we also apply the dynamic panel data method using the asymmetric Pooled Mean Group analysis (PMG) because this region has been conducting economic integration since 1992.

\section{Literature review}

Most of the empirical studies affirm the unemployment-output tradeoff as expected in Okun's law. However, the question comes up whether the coefficient of unemployment-output tradeoff is in line with Okun's prediction. Many empirical studies documented that the estimated coefficient of Okun are not close to Okun's prediction by $3 \%$, but it is various from different countries as well as different period. Lee (2000), Ball (2017), Ball, Furceri, Leigh, and Loungani (2019) and An, Ball, Jalles, and Loungani (2019) are among them who question Okun's law predictions. Lee (2000) found that the coefficient estimates of Okun lie between 1 and 4 percentage for 16 OECD countries. Ball (2017) indicated that the coefficient of Okun, by contrast, ranges from $0.4 \%$ for the United States from 1948 to $0.5 \%$ for 20 advanced countries since 1980, but it varies across countries. Ball, Furceri, Leigh, and Loungani (2019) explore the presence of the unemployment-output tradeoff in both developed and developing economies. They found that Okun's coefficient of most developing countries is twice as in advanced countries.

There are two approaches in calculating GDP, namely the expenditure approach and the production approach. The expenditure approach produces several expenditure components such as private consumption, investment, government spending, and export and import. Each component of expenditure has a different impact on unemployment (Anderton, Aranki, Bonthuis, \& Jarvis, 2014). Based on this fact, the empirical researches regarding the disaggregated Okun's law are increasing. The disaggregated approach investigates the 
different responses of unemployment to changes in the expenditure components of GDP. Anderton, Aranki, Bonthuis, and Jarvis (2014) and Andonova and Petrovska (2019) augment the standard Okun's law to take account of disaggregate Okun's law, which decomposes aggregate GDP into four expenditure components. Anderton, Aranki, Bonthuis, and Jarvis (2014) documented that a strong tradeoff between unemployment and domestic demand is present, especially consumption expenditure in the Euro area over the period 1996Q12013Q4. However, the tradeoff between unemployment and foreign trade both exports and imports are weak. Andonova and Petrovska (2019) also found that domestic demand has a stronger impact than foreign demand on unemployment in Macedonia.

An investigation of the unemployment-output relationship focuses on the national level and ignores that relationship at the regional level. The unemployment-output relationship at the aggregate level is not able to explain this relationship at the regional level because each region has different economic conditions (Christopoulus, 2004; Durech, Minea, Mustea, \& Slusna, 2014) The empirical researches of Okun's law then are extended to cases at the regional level. Christopoulus (2004) explored Okun's law in Greece because the population, economic activities, and infrastructure are concentrated in some regions. His findings confirm Okun's law for six out of the 13 regions in Greece. Kangasharju, Tavera, and Nijkamp (2012) documented the long-run relationship between unemployment and output for the regions in Finland, but the regional coefficients of Okun are smaller than that of the aggregate level. Durech, Minea, Mustea, and Slusna (2014) show the evidence of a negative relationship between unemployment and output in the Czech Republic and Slovakia. The unemployment-output tradeoff is confirmed in 5 out of 8 regions for the Slovakia and 11 out of 14 regions for the Czech Republic. Palombi, Perman, and Tavéra (2015) examined Okun's relationship for regions in the UK. Their results assure the Okun relationship in the medium run but the coefficient of Okun at the national level is higher than those of the regional level.

Some empirical studies document that economic upturns and downturns may result in different effects on the unemployment (Lee, 2000; Harris \& Silverstone, 2001; Virén, 2001; Silvapulle, Moossa, \& Silvapulle, 2004; Kim, Park, \& Jei, 2015; Tang \& Bethencourt, 2017). Their studies clearly show evidence that the relationship between unemployment and output is nonlinear. Precisely, unemployment-output relation is asymmetry instead of symmetry both in the short-run and long-run conditions. In the existing empirical study of unemploymentoutput tradeoff at the aggregate level, the asymmetric Okun's law exists in several countries such as Silvapulle, Moossa, and Silvapulle (2004) and Belaire-Franch and Peiró (2014) for the US; Belaire-Franch and Peiró (2014) for the UK; Koutroulis, Panagopoulos, and Tsouma (2016) for Greece; Cevik, Dibooglu, and Barişik (2013) for transition economies; Harris and Silverstone (2001) for OECD Countries; Kim, Park, and Jei (2015) for the Asian Countries; Tang and Bethencourt (2017) for Euro Zone. Furthermore, Asymmetric Okun's law also is found at the regional level (Marinkov \& Geldenhuys, 2007; Palombi, Perman \& Tavéra, 2015).

\section{Methodological approach}

\subsection{Cointegration analysis}

Our study about the unemployment and output relationship stems from Okun's law. The law clearly states that there is an unemployment-output tradeoff. If output rises, unemployment falls, and vice versa, output decreases, unemployment rises. The model specifications for estimating Okun's law can be formulated as: 


$$
\Delta U N_{t}=\beta \Delta G D P_{t}+e_{t}
$$

where $\Delta U N_{t}$ shows the unemployment rate, $\triangle G D P$ is the gross domestic product, and $e_{t}$ is an error term. The coefficient of Okun is expressed by $\beta$. The long-run equilibrium relationship between unemployment and output can be stated in the following equation:

$$
U N_{t}=\alpha+\beta G D P_{t}+e_{t}
$$

The long-run equilibrium relationship between unemployment and output in equation (2) can be estimated by the cointegration approach. Our study applies the ARDL model to examine for cointegration as in equation (2) as follows:

$$
\Delta U N_{t}=\pi_{0}+\pi_{1} U N_{t-1}+\pi_{2} G D P_{t-1}+\sum_{i=1}^{l} \gamma_{1 i} \Delta U N_{t-1}+\sum_{i=1}^{p} \gamma_{2 i} \Delta G D P_{t-1}+\mu_{t}
$$

Where $\pi_{1}$ and $\pi_{2}$ are the long-run coefficients, $\gamma_{1 i}$ and $\gamma_{2 i}$ are the short-run coefficients, and $l$ and $p$ are the optimal lags. We apply the OLS method to estimate equation (3) with the optimal lag up to 4. The optimal lag is selected by sequentially trimming insignificant lag (Shin, Yu, \& Greenwood-nimmo, 2014). The ARDL model stems from the long-run relationship among the variables. This cointegration is tested following the bound testing approach, checking the null hypothesis of no cointegration $\pi_{1}=\pi_{2}=0$ (Pesaran, Shin, \& Smith, 2001).

Okun's law in equation (2) which represents the long-run equilibrium relationship between unemployment and output is the symmetric relationship. The linear ARDL model to test equation (2) considers that rising and falling output symmetrically affects unemployment. However, the existing empirical literature documents that the unemployment-output tradeoff may be an asymmetric instead of a symmetric pattern (Tang \& Bethencourt, 2017). The changes in positive and negative output have a different impact on unemployment. The longrun asymmetric relationship between unemployment and output can be formulated as follows:

$$
U N_{t}=\alpha+\rho^{+} G D P_{t}^{+}+\rho^{-} G D P_{t}^{-}+e_{t}
$$

$G D P_{t}^{+}$and $G D P_{t}^{-}$are partial sums of positive and negative change in output, respectively. Following Shin, $\mathrm{Yu}$, and Greenwood-nimmo (2014), $G D P_{t}^{+}$and $G D P_{t}^{-}$are calculated as,

$$
\begin{aligned}
& G D P_{i}^{+}=\sum_{i=1}^{t} \Delta G D P_{i-1}^{+}=\sum_{i=1}^{t} \max \left(G D P_{i}, 0\right) \\
& G D P_{i}^{-}=\sum_{t=1}^{t} \Delta G D P_{i-1}^{-}=\sum_{i=1}^{n} \min \left(G D P_{i}, 0\right)
\end{aligned}
$$

We apply a nonlinear ARDL (NARDL) to examines both the short-run and long-run asymmetries effect of output on the unemployment following Shin, Yu, and Greenwoodnimmo (2014). The following equation is the NARDL model of equation (4):

$$
\begin{aligned}
\Delta U N_{t}= & \omega_{0}+\omega_{1} U N_{t-1}+\omega_{2}^{+} G D P_{t-1}^{+}+\omega_{2}^{-} G D P_{t-1}^{-}+\sum_{i=1}^{l} \rho_{1 i} \Delta U N_{t-1}+ \\
& \sum_{i=0}^{m} \sigma_{i}^{+} \Delta G D P_{t-1}^{+}+\sum_{i=0}^{n} \sigma_{i}^{-} \Delta G D P_{t-1}^{-}+\mu_{t}
\end{aligned}
$$

According to Shin, Yu, and Greenwood-nimmo (2014), the asymmetric impact of output on unemployment both in the short-run and long-run can be captured by the NARDL in equation (7). The long-run asymmetric effects of upturn and downturn in output on unemployment are calculated by $\varphi^{+}=-\frac{\omega_{2}^{+}}{\omega_{1}}$ and $\varphi^{-}=-\frac{\omega_{2}^{-}}{\omega_{1}}$. Accordingly, the short-run 
asymmetric effects of upturn and downturn in output on unemployment are measured by $\pi^{+}=\sum_{i=0}^{m} \sigma_{i}^{+} \Delta G D P_{t-1}^{+}$and $\pi^{-}=\sum_{i=0}^{m} \sigma_{i}^{-} \Delta G D P_{t-1}^{-}$.

We take some steps to estimate equation (7) as in Shin, Yu, and Greenwood-nimmo (2014). In the first step, we estimate equation (7) by applying the OLS method. To get the final specification of equation (7), we apply the general-to-specific method with optimal lag up to 4 lag by sequentially dropping insignificant lag. In the second step, we carry out a cointegration test to check the long-run relationship between unemployment and output. The bounds testing approach is applied to check the cointegration (Pesaran, Shin, \& Smith, 2001). This test follows the Wald F test. The null hypotheses of no cointegration are $\omega_{1}=\omega_{2}^{+}=$ $\omega_{2}^{-}=0$. In the third step, our study carries out the long-run asymmetric impact of output on employment. The null hypothesis of the long-run asymmetric impact of output on unemployment is $\varphi^{+}=\varphi^{-}$. An upturn (a downturn) in output asymmetrically affects unemployment for the long-run as the null hypothesis of no asymmetric effect is rejected. In the last step, we calculate the long-run asymmetric coefficient of positive output $\left(\varphi^{+}\right)$and negative output $\left(\varphi^{-}\right)$on unemployment.

\subsection{Panel analysis}

Supported by the economic integration in the South East Asian countries since 1992, we also apply the dynamic panel data method. The standard panel estimator methods permit intercepts to vary across the country but the same slopes across the country. Restricting the same slope across the country, however, causes inconsistent long-run coefficients with large samples (Pesaran, Pesaran, Shin, \& Smith, 1999). Generally, two estimation methods could be applied to the panel data method. Those methods are the standard panel estimator methods consisting of the fixed, random effect, and the Generalized Method of Moments (GMM) methods, and the Mean Group (MG) method (Pesaran \& Smith, 1995). The MG does not allow homogeneity between countries but it considers estimates to be different across countries in both the short-run and long-run. Meanwhile, the Pooled Mean Group (PMG) permits the long-run coefficients are the same, but it is the robust heterogeneous panel that considers short-run coefficients, intercepts, adjustment processes to equilibrium condition, and error variances to be different for each country. The PMG model is a pooled errorcorrection model to which short-run and long-run coefficients are generated from an ARDL model and the short-run coefficients are allowed to be varied across countries.

A symmetric PMG model can be written in term of the symmetric panel ARDL as

$$
\Delta U N_{i t}=\pi_{0 i}+\pi_{1} U N_{i t-1}+\pi_{2} G D P_{t-1}+\sum_{i=1}^{l} \gamma_{i j} \Delta U N_{i t-1}+\sum_{i=1}^{p} \delta_{i j} \Delta G D P_{i t-1}+\mu_{i t}
$$

Where $i=1,2, \ldots, n$ countries and $t=1,2, \ldots, t$ number of observation, $\pi_{0 i}$ show countryspecific intercepts, $\gamma_{i j}$ and $\delta_{i j}$ are the short-run country-specific coefficient. The long-run impact of output on unemployment is measured by $-\frac{\pi_{2}}{\pi_{1}}$ and the short-run effect is measured by $\delta_{i j}$.

To generate an asymmetric PMG model, we include the partial sum of an increase in output $\left(G D P_{i t}^{+}\right)$and a decrease in output $\left(G D P_{i t}^{-}\right)$. Therefore, the asymmetric PMG model can be formulated as

$$
\begin{aligned}
\Delta U N_{i t}= & \gamma_{0}+\gamma_{1} U N_{i t-1}+\gamma_{2}^{+} G D P_{i t-1}^{+}+\gamma_{2}^{-} G D P_{i t-1}^{-}+\sum_{i=1}^{l} \rho_{i} \Delta U N i_{t-1}+ \\
& \sum_{i=0}^{m} \delta_{i j}^{+} \Delta G D P_{i t-1}^{+}+\sum_{i=0}^{n} \delta_{i j}^{-} \Delta G D P_{i t-1}^{-}+\mu_{i t}
\end{aligned}
$$


The positive and negative long-run effects of output on unemployment are captured by $\beta^{+}=-\frac{\gamma_{2}^{+}}{\gamma_{1}}$ and $\beta^{-}=-\frac{\gamma_{2}^{-}}{\gamma_{1}}$, respectively. The short-run adjustments of unemployment to changes in positive and negative output are given by $\delta_{i j}^{+}$and $\delta_{i j}^{-}$.

We carry out panel unit roots and panel cointegration tests before estimating the PMG model to ascertain the order of integration and cointegration of the variables. Our study employs two panel unit root tests. First, following Levin, Lin, and Chu (2002), we examine a common unit root process across the country. Second, we allow the unit root process for each across the country to be heterogeneous suggested by Im, Pesaran, and Shin (2003) which is less restrictive and more powerful than the first method. Having the integration order of the variables is established, the long-run relationship among the variables is tested by applying the panel cointegration test. Our study employs the Pedroni panel cointegration test that allows the intercepts and trend coefficients to be heterogeneous across the country (Pedroni, 1999).

\subsection{Data}

We use quarterly data for each country. The period of time is different across countries depending on the data availability. Malaysia covers from 1998:Q1-2018:Q4, the Philippines spans from 1992:Q2-2018:Q4, and Singapore covers 1992:Q1-2018:Q4. Unemployment is the unemployment rate (percent) which is measured by the ratio of unemployment (persons) to the total labor force (persons) for each country. The output is real GDP, which is adjusted for Inflation $(2010=100)$. Real GDP is measured in thousand \$ US for each country. The unemployment rate, nominal GDP, and consumer price index are collected from International financial statistics.

\section{Conducting research and results}

Table 1 exhibits the average unemployment rates and the average real GDP over the period 1992-2018 and for different sub-periods in the ASEAN-3. In general, the highest unemployment rate was in the Philippines and the smallest unemployment was Singapore. The highest average GDP is in Malaysia and the lowest GDP in the Philippines. The unemployment rate was highest during 1998-2008 periods because the economic crisis hit some Southeast Asia in 1998. Similarly, the average real GDP was lowest in that period due to the economic crisis. A negative correlation exists for all period but with a different coefficient of correlation. These preliminary results confirm that the unemployment-output tradeoff is found in the ASEAN-3.

Before estimating both the ARDL and NARDL model, we have to check the stationary of the variables. We utilize the Augmented Dickey-Fuller (ADF) and Phillips and Perron (PP) test with no trend and trend to examine the stationarity of unemployment and real GDP variables. Table 2 provides a stationary test. Unemployment data indicate to be stationary in level or I(0) as well as the first differences or I(1) for all countries. Real GDP is not stationary in level but stationary in the first differences for all countries. Generally, the results show that variables seem to be integrated of different order either I(0) or I(1) but I(2) is not found, which ensure the use of both the ARDL as well as NARDL model. 
Table 1 Descriptive statistics

\begin{tabular}{|c|c|c|c|c|c|c|}
\hline \multirow[t]{2}{*}{ Country } & \multirow[t]{2}{*}{ Period } & \multirow{2}{*}{$\begin{array}{c}\text { UN } \\
\text { Mean }\end{array}$} & \multicolumn{3}{|c|}{ GDP } & \multirow[t]{2}{*}{ Correlation } \\
\hline & & & Std. Dev & Mean & Std. Dev & \\
\hline \multirow[t]{3}{*}{ Malaysia } & 1998Q1-2018Q4 & 3.335 & 0.313 & 51.738 & 18.738 & -0.386 \\
\hline & 1998Q1-2008Q4 & 3.414 & 0.350 & 36.585 & 11.296 & -0.120 \\
\hline & 2009Q1-2018Q4 & 3.248 & 0.241 & 68.405 & 7.912 & -0.789 \\
\hline \multirow[t]{4}{*}{ Philippines } & 1992Q1-2018Q4 & 8.482 & 2.169 & 44.997 & 12.905 & -0.804 \\
\hline & 1998Q1-2018Q4 & 8.273 & 2.299 & 45.875 & 14.355 & -0.832 \\
\hline & 1998Q1-2008Q4 & 9.815 & 2.096 & 34.173 & 6.365 & -0.682 \\
\hline & 2009Q1-2018Q4 & 6.575 & 0.873 & 58.748 & 8.333 & -0.775 \\
\hline \multirow[t]{4}{*}{ Singapore } & 1992Q1-2018Q4 & 3.109 & 1.142 & 44.142 & 19.982 & -0.179 \\
\hline & 1998Q1-2018Q4 & 3.394 & 1.112 & 49.821 & 18.995 & -0.597 \\
\hline & 1998Q1-2008Q4 & 3.877 & 1.108 & 33.817 & 9.303 & -0.335 \\
\hline & 2009Q1-2018Q4 & 2.863 & 0.852 & 67.428 & 8.099 & -0.688 \\
\hline
\end{tabular}

Source: International Financial Statistics (IFS).

Note: Unemployment is the unemployment rate (percent) and GDP is real GDP (thousand US\$)

Table 2. Unit root test

\begin{tabular}{|c|c|c|c|c|c|c|c|c|}
\hline & \multicolumn{4}{|c|}{ Level data } & \multicolumn{4}{|c|}{ First difference data } \\
\hline & \multicolumn{2}{|c|}{$\mathrm{ADF}$} & \multicolumn{2}{|c|}{ PP } & \multicolumn{2}{|c|}{$\mathrm{ADF}$} & \multicolumn{2}{|c|}{ PP } \\
\hline Variable & No trend & Trend & No trend & Trend & No trend & Trend & No trend & Trend \\
\hline un_mas & $-5.88 * * *$ & $-6.20 * * *$ & $-5.88 * * *$ & $-6.25 * * *$ & $-8.16 * * *$ & $-8.10 * * *$ & $-25.51 * * *$ & $-25.22 * * *$ \\
\hline$g d p \_m a s$ & -1.11 & -2.09 & -1.03 & -1.76 & $-6.94 * * *$ & $-6.91 * * *$ & $-6.74 * * *$ & $-6.68 * * *$ \\
\hline un_phi & -0.44 & -1.63 & $-4.61 * * *$ & $-7.35 * * *$ & $-14.01 * * *$ & $-14.02 * * *$ & $-24.84 * * *$ & $-24.68 * * *$ \\
\hline$g d p \_p h i$ & 0.05 & -1.32 & -1.05 & $-3.17 *$ & $-5.41 * * *$ & $-5.57 * * *$ & $-24.87 * * *$ & $-25.98 * * *$ \\
\hline un_sin & -2.43 & -2.37 & $-7.39 * * *$ & $-7.36 * * *$ & $-5.25 * * *$ & $-5.33 * * *$ & $-30.55 * * *$ & $-31.25 * * *$ \\
\hline$g d p_{s} \sin$ & 0.30 & -1.62 & 0.25 & -1.75 & $-10.06 * * *$ & $-10.07 * * *$ & $-10.08 * * *$ & $-10.09 * * *$ \\
\hline
\end{tabular}

Note: $* * *, * *, *$ reject the null hypothesis at the $1 \%, 5 \%$ and $10 \%$. Mas, phi, and sin stand for Malaysia, the Philippines, and Singapore

\subsection{ARDL results}

Having known that all of the variables are integrated of order 1 or I(1) without $\mathrm{I}(2)$, we first continue to estimating the linear ARDL model in equation (3). The upper part of Table 3 exhibits the ARDL estimation and diagnostic test. The coefficient of determination $\left(R^{2}\right)$ ranges from 0.412 for Malaysia to 0.749 for Singapore. Before inferences are concluded, we first take some diagnostic statistics tests. The statistics tests consist of the Jarque-Berra (JB) test for error normality, Lagrange Multiplier (LM) test for autocorrelation, Autoregressive conditional heteroskedasticity $(\mathrm{ARCH})$ test for heteroskedasticity, RESET test for functional misspecification, and CUSUM test for parameter stability. The diagnostic check for error normality exists in Singapore. The lack of autocorrelation exists in all the cases except Malaysia. The existence of homoskedasticity is for Malaysia. The lack of functional misspecification is in all countries. The stability tests confirm parameter stability in all the cases. The cointegration test using $F_{P S S}$ suggests that the long-run relationship between unemployment and output is found for Malaysia.

We now turn to the symmetric effect of output on unemployment both short-run and long-run which is exhibited in the bottom of table 3. The symmetric unemployment -output tradeoff exists in the short-run. The short-run coefficient of Okun differs among the countries, varying from -0.020 for Malaysia to -0.205 for the Philippines. The long-run Okun 
relationship is negative and significant for all the countries except Singapore. The long-run coefficients of Okun are from -0.006 for Malaysia to -0.138 for the Philippines. These findings may suggest that an economic boom (downturn) of $1 \%$ leads to falling (rising) unemployment rate by $0.006 \%, 0.027 \%$, and $0.138 \%$ in the long-run for Malaysia, Singapore, and the Philippines, respectively. These findings conclude that the short-run and long-run coefficient of Okun vary among countries. However, generally coefficient of Okun is higher for less emerging countries such as the Philippines because of high unemployment. These findings support the previous empirical study such as Ball, Furceri, Leigh, and Loungani (2019) who report that the coefficient of Okun is higher in developing countries than in advanced countries.

Table 3. ARDL estimation results and diagnostic test

\begin{tabular}{|c|c|c|c|c|c|c|}
\hline \multicolumn{3}{|c|}{ Malaysia } & \multicolumn{2}{|l|}{ Philippines } & \multicolumn{2}{|l|}{ Singapore } \\
\hline Variable & Coeff. & Prob. & Coeff. & Prob. & Coeff. & Prob. \\
\hline$C$ & $2.491 * * *$ & 0.000 & $4.307 * *$ & 0.030 & $0.736^{* *}$ & 0.015 \\
\hline$u n_{t-1}$ & $-0.686 * * *$ & 0.000 & $-0.296^{* *}$ & 0.027 & $-0.149 * *$ & 0.041 \\
\hline$g d p_{t-1}$ & $-0.004 * *$ & 0.033 & $-0.041 * *$ & 0.039 & -0.004 & 0.226 \\
\hline$\Delta u n_{t-1}$ & & & $-0.580 * * *$ & 0.000 & $-0.385^{* * *}$ & 0.000 \\
\hline$\Delta u n_{t-2}$ & & & $-0.445^{* * *}$ & 0.000 & $-0.218 * *$ & 0.026 \\
\hline$\Delta u n_{t-3}$ & & & $-0.335 * * *$ & 0.000 & $-0.258 * * *$ & 0.006 \\
\hline$\Delta u n_{t-4}$ & & & & & $0.350 * * *$ & 0.000 \\
\hline$\Delta g d p_{t}$ & & & $-0.112 * * *$ & 0.000 & & \\
\hline$\Delta g d p_{t-1}$ & & & $-0.094 * * *$ & 0.003 & $-0.139 * * *$ & 0.000 \\
\hline$\Delta g d p_{t-4}$ & $-0.020 * *$ & 0.057 & & & & \\
\hline$R^{2}$ & 0.412 & & 0.567 & & 0.749 & \\
\hline \multicolumn{7}{|c|}{ Diagnostic test } \\
\hline JB & 5.817 & 0.055 & 46.566 & 0.000 & 3.206 & 0.201 \\
\hline LM & 8.449 & 0.004 & 1.489 & 0.222 & 0.078 & 0.781 \\
\hline$\overline{\mathrm{ARCH}}$ & 1.039 & 0.308 & 7.027 & 0.008 & 4.915 & 0.027 \\
\hline RESET & 2.082 & 0.153 & 0.153 & 0.697 & 1.816 & 0.181 \\
\hline CUMSUM & stable & & stable & & Stable & \\
\hline CUSUMSQ & unstable & & unstable & & Stable & \\
\hline \multicolumn{7}{|c|}{ Cointegration test } \\
\hline$F_{P S S}$ & $24.559 * * *$ & & 2.542 & & 2.479 & \\
\hline \multicolumn{7}{|c|}{ Short-run symmetric } \\
\hline$g d p$ & $-0.020^{*}$ & 0.057 & $-0.205 * * *$ & 0.000 & $-0.139 * *$ & 0.000 \\
\hline \multicolumn{7}{|c|}{ Long-run symmetric } \\
\hline$g d p$ & $-0.006^{* *}$ & 0.019 & $-0.138 * * *$ & 0.000 & -0.027 & 0.248 \\
\hline
\end{tabular}

Note: $* * *, * *, *$ reject the null hypothesis at the $1 \%, 5 \%$ and $10 \%$. With $\mathrm{k}=1$, the Upper bounds are 4.78, 5.73, and 7.84 and the lower bounds are 4.04, 4.94, and 6.84 for $10 \%, 5 \%$, and 1\% significance level (Pesaran, Shin, \& Smith, 2001).

\subsection{NARDL results}

Given that none of the variables is I(2) and the possibility of nonlinearities and asymmetric Okun's law as the previous discussion, out study employs the NARDL to examine the asymmetric impact of output changes on unemployment following Shin, $\mathrm{Yu}$, and Greenwood-nimmo (2014). Similar to ARDL, we estimate NARDL by applying the OLS method with the optimal lag number up to 4 lags. This study applies the general-to-specific method by consecutively getting rid of insignificant lag. Table 4 exhibits the estimation 
results of the NARDL model. The coefficient of determination $\left(R^{2}\right)$ is from 0.407 for Malaysia to 0.775 for Singapore. The JB test for error normality exists in Singapore. The LM test for the absence of autocorrelation exists in all the cases at the 5\% significance level. The ARCH test for the absence of heteroskedasticity is found for the Philippines and Singapore. The lack of functional misspecification is in Malaysia. The CUSUM tests suggest parameter stability in all the countries. The cointegration test following $F_{P S S}$ affirms that the long-run relationship between unemployment and output is present for Malaysia and Singapore but it is unclear for the Philippines since the $F_{P S S}$ is between the critical lower bound and upper bound.

Before estimating the asymmetric coefficient of Okun, we have to check the short-run and long-run asymmetric test of output on unemployment, following the Wald test $W_{S R}$ for the short-run and $W_{L R}$ for long-run. Rising and falling output affect unemployment in the short-run for only the Philippines. We fail to reject the null hypothesis of the short-run symmetric for the Philippines. A decrease in output influences unemployment in the short-run for Malaysia and Singapore. The findings suggest that failing output is significant and leads to unemployment to rise in the short-run for all the countries. The negative short-run coefficients are from -0.038 for Malaysia to -0.384 for Singapore. The results may suggest that an economic downturn of $1 \%$ escalates the unemployment rate by $0.0395 \%, 0.128 \%$, and $0.389 \%$ in Malaysia, the Philippines, and Singapore, respectively, in the short-run. The positive short-run coefficient is statistically significant for only the Philippines, concluding that an economic boom of $1 \%$ lowers the unemployment rate by $0.142 \%$ in the Philippines.

We now turn to long-run asymmetric Okun's law. The null hypothesis of the long-run symmetric for Malaysia and Singapore is rejected. These results imply that rising and falling output asymmetrically affect the unemployment rate for Malaysia and Singapore in the longrun. Although long-run asymmetry fails to be rejected for the Philippines, the results suggest that an increase and a decrease in output have a significant long-run impact on the unemployment rate in the Philippines. The long-run coefficient on $L g d p^{+}$and $L g d p^{-}$is 0.013 and $-0,019$ for Malaysia, -0.106 and -0.098 for the Philippines, -0.105 and -0.209 for Singapore, respectively. These results may suggest that an economic upturn of $1 \%$ lessens the unemployment rate by $0.013 \%,-0.106 \%$, and $0.105 \%$ in Malaysia, the Philippines, and Singapore, respectively. By contrast, an economic downturn of $1 \%$ escalates the unemployment rate by $0.019 \%, 0.098 \%$, and $0.209 \%$ in Malaysia, the Philippines, and Singapore.

The positive or negative long-rung asymmetric Okun varies across the country. Singapore suffers from high unemployment as an economic downturn hits that country due to a small open economy. In addition, output relies on the service industry and most of their labor is skilled labor and foreign workers. Meanwhile, the Philippines, which relies on agricultural export products, can create more jobs than other countries when an economic upturn likely occurs because most of their labor is unskilled labor and the country has the worst unemployment in Southeast Asian countries. The Okun's coefficients of Malaysia are lowest, suggesting unemployment is not responsive to output changes because their industries rely on labor-intensive industries. Generally, the economic downturn is a stronger impact on unemployment than economic upturn, except for the Philippines. Our findings are supported by some existing empirical studies such as Harris and Silverstone (2001) for the OECD Countries, Koutroulis, Panagopoulos, and Tsouma (2016) for Greece, and Tang and Bethencourt (2017) for the Eurozone. 
Table 4. NARDL estimation results and diagnostic test

\begin{tabular}{|c|c|c|c|c|c|c|}
\hline & Malaysia & & Philippines & & Singapore & \\
\hline Variable & Coeff. & Prob. & Coeff. & Prob. & Coeff. & Prob. \\
\hline$c$ & $2.516^{* * *}$ & 0.000 & $4.325^{* * *}$ & 0.001 & $0.833^{* * *}$ & 0.011 \\
\hline$u n_{t-1}$ & $-0.710 * * *$ & 0.000 & $-0.431 * * *$ & 0.001 & $-0.262 * * *$ & 0.005 \\
\hline$g d p_{t-1}^{+}$ & $-0.009 * * *$ & 0.001 & $-0.045 * *$ & 0.019 & $-0.027 * *$ & 0.015 \\
\hline$g d p_{t-1}^{-}$ & $-0.014 * * *$ & 0.008 & $-0.042 * *$ & 0.042 & $-0.055 * *$ & 0.033 \\
\hline$\Delta u n_{t-1}$ & & & $-0.343 * * *$ & 0.002 & $-0.422 * * *$ & 0.000 \\
\hline$\Delta u n_{t-2}$ & & & $-0.166^{*}$ & 0.050 & $-0.256 * *$ & 0.010 \\
\hline$\Delta u n_{t-3}$ & & & & & $-0.305 * * *$ & 0.001 \\
\hline$\Delta u n_{t-4}$ & & & $0.245^{* * *} *$ & 0.000 & $0.301 * * *$ & 0.001 \\
\hline$\Delta g d p_{t}^{+}$ & & & $-0.142 * * *$ & 0.000 & & \\
\hline$\Delta g d p_{t}^{-}$ & $-0.039 * *$ & 0.033 & & & & \\
\hline$\Delta g d p_{t-1}^{-}$ & & & $-0.128 * * *$ & 0.003 & $-0.222 * * *$ & 0.002 \\
\hline$\Delta g d p_{t-2}^{-}$ & & & & & $-0.162 * *$ & 0.026 \\
\hline$R^{2}$ & 0.407 & & 0.579 & & 0.775 & \\
\hline \multicolumn{7}{|l|}{ Diagnostic } \\
\hline JB & 12.170 & 0.002 & 31.778 & 0.000 & 3.099 & 0.216 \\
\hline LM & 1.754 & 0.185 & 0.885 & 0.347 & 3.602 & 0.058 \\
\hline $\mathrm{ARCH}$ & 5.969 & 0.015 & 0.816 & 0.366 & 1.277 & 0.258 \\
\hline RESET & 1.404 & 0.240 & 7.086 & 0.009 & 4.730 & 0.032 \\
\hline CUSUM & stable & & stable & & stable & \\
\hline CUSUMSQ & stable & & unstable & & stable & \\
\hline \multicolumn{7}{|l|}{ Cointegration } \\
\hline$F_{P S S}$ & $14.226 * * *$ & 0.000 & 4.148 & 0.008 & $4.172 *$ & 0.008 \\
\hline \multicolumn{7}{|l|}{ Asymmetric } \\
\hline$W_{L R}$ & $3.232 *$ & 0.076 & 1.114 & 0.294 & $6.212 * *$ & 0.015 \\
\hline$W_{S R}$ & & & 0.094 & 0.760 & & \\
\hline \multicolumn{7}{|l|}{ Short-run } \\
\hline$S g d p^{+}$ & & & $-0.142 * * *$ & 0.000 & & \\
\hline$S g d p^{-}$ & $-0.039 * * *$ & 0.033 & $-0.128 * * *$ & 0.003 & $-0.384 * * *$ & 0.000 \\
\hline \multicolumn{7}{|l|}{ Long-run } \\
\hline $\operatorname{Lgdp^{+}}$ & $-0.013 * * *$ & 0.001 & $-0.106^{* * *}$ & 0.001 & $-0.105 * * *$ & 0.002 \\
\hline$L g d p^{-}$ & $-0.019 * * *$ & 0.004 & $-0.098 * * *$ & 0.007 & $-0.209 * * *$ & 0.005 \\
\hline
\end{tabular}

Note: ***, **, * reject the null hypothesis at the $1 \%, 5 \%$ and $10 \%$. With $\mathrm{k}=1$, the Upper

bounds are 4.78, 5.73 and 7.84 and the lower bounds are 4.04, 4.94 and 6.84 for $10 \%, 5 \%$ and $1 \%$ significance level (Pesaran, Shin, \& Smith, 2001).

\subsection{Panel results}

We begin with the panel analysis by examining panel unit-roots to check the integration order of the variables. We first employ Levin, Li, and Chu (LCC) test that assumes the unit-roots process for each country is a homogenous suggested by Levin, $\mathrm{Li}$, and Chu (2002). We then proceed Im, Pesaran, and Shin (IPS) test that allows the unit-roots process for each country are heterogeneous recommended by Im, Pesaran, and Shin (2003). The findings, exhibited in Table 6, indicate that the unemployment rate is level stationary and real GDP is the first difference stationary. Given that results, we infer that all the variables are stationary in the first differences. 
Table 5. Panel Unit root

\begin{tabular}{|c|c|c|c|c|c|c|c|c|}
\hline \multirow[b]{3}{*}{ Var. } & \multicolumn{4}{|c|}{ LLC test } & \multicolumn{4}{|c|}{ IPS test } \\
\hline & \multicolumn{2}{|c|}{ Level } & \multicolumn{2}{|c|}{ First difference } & \multicolumn{2}{|c|}{ Level } & \multicolumn{2}{|c|}{ First difference } \\
\hline & No trend & Trend & No trend & Trend & No trend & Trend & No trend & Trend \\
\hline $\mathrm{UN}$ & $-1.37 *$ & $-3.86 * * *$ & $-12.72 * * *$ & $-12.32 * * *$ & $-2.19 * *$ & $-4.27 * * *$ & $-19.44 * * *$ & $-19.94 * * *$ \\
\hline GDP & 0.10 & -0.30 & $-6.04 * * *$ & $-5.55 * * *$ & 1.88 & -0.68 & $-12.22 * * *$ & $-12.11 * * *$ \\
\hline
\end{tabular}

Note: ***,**,* reject of the null hypothesis at the $1 \%, 5 \%$ and $10 \%$.

Next, we apply the Pedroni test to examine the cointegration showing the existence of a long-run relationship among the variables. The Pedroni test provides two statistical tests. The first test consists of four tests from estimators pooling the autoregressive coefficients across countries for the unit root test on the residuals. The second test encompasses three tests which are stemmed from estimators taking average individual coefficients for each country. Table 6 provides the results of the Pedroni test for both symmetric and asymmetric models of Okun's law. The Pedroni test may conclude that the long-run relationship among the variables both symmetric and asymmetric model is present.

Table 6. Panel cointegration

\begin{tabular}{lcccc}
\hline & Symmetric model & \multicolumn{3}{c}{ Asymmetric model } \\
\hline Statistic test & No trend & Trend & No trend & Trend \\
\hline Panel v-Statistic & $2.032^{* *}$ & 0.197 & $7.048^{* * *}$ & $4.462^{* * *}$ \\
\hline Panel rho-Statistic & $-20.866^{* * *}$ & $-17.317 * * *$ & $-4.001 * * *$ & $-2.764 * * *$ \\
\hline Panel PP-Statistic & $-11.103^{* * *}$ & $-12.463^{* * *}$ & $-3.622^{* * *}$ & $-3.230^{* * *}$ \\
\hline Panel ADF-Statistic & $-4.959^{* * *}$ & $-4.963^{* * *}$ & 0.219 & 1.192 \\
\hline Group rho-Statistic & $-17.216^{* * *}$ & $-14.171^{* * *}$ & $-4.368^{* * *}$ & $-2.575^{* * *}$ \\
\hline Group PP-Statistic & $-12.312^{* * *}$ & $-13.205^{* * *}$ & $-3.610^{* * *}$ & $-2.454 * * *$ \\
\hline Group ADF-Statistic & $-6.766^{* * *}$ & $-6.868^{* * *}$ & 1.038 & 2.159 \\
\hline
\end{tabular}

Note: $* * *, * *, *$ reject the null hypothesis at the $1 \%, 5 \%$ and $10 \%$.

We then continue to estimating the panel PMG model having established the existence of cointegration. The results of the symmetric and asymmetric panel PMG model are exhibited in Table 7. The findings of the symmetric PMG model conclude that output has a significant long-run negative effect on the unemployment rate in the ASEAN-3. The long-run coefficient of Okun is -0.038 , implying that a $1 \%$ increase in output leading to an approximately $0.03 \%$ increase in unemployment rate vice versa. Turning to the short-run effect, the error-correction term $\left(E C_{t-1}\right)$ is negative and significant at $10 \%$, which assures the evidence of a long-run relationship. Output has a positive and significant impact on the unemployment rate. Moreover, the lagged unemployment variables are significant, indicating that the ASEAN-3 face persistent unemployment.

We now turn to the asymmetric panel PMG model. The findings of the asymmetric PMG model suggest that we reject the null hypothesis and output asymmetrically affect unemployment in the long-run in the ASEAN-3. The positive and negative long-run coefficients of Okun are -0.053 and $0-0.081$, indicating that an economic boom of $1 \%$ lessens the unemployment rate approximately by $0.053 \%$ while an economic downturn of $1 \%$ raises the unemployment rate by roughly $0.081 \%$. The asymmetric panel PMG model also confirms that economic downturns have a stronger effect on the unemployment rate than economic upturns. Turning to the short-run effect, the error-correction term $\left(E C_{t-1}\right)$ is negative and statistically significant at $10 \%$, which suggests the presence of a long-run relationship. Output has no significant effect on unemployment but lagged unemployment variables are significant, suggesting that unemployment is permanent in the ASEAN-3. 
Table 7. Pool mean group (PMG) estimation

\begin{tabular}{|c|c|c|c|c|c|}
\hline \multirow[b]{2}{*}{ Variable } & \multicolumn{2}{|c|}{ Symmetric } & \multirow[b]{2}{*}{ Variable } & \multicolumn{2}{|c|}{ Asymmetric } \\
\hline & Coeff. & Prob. & & Coeff. & Prob. \\
\hline \multicolumn{6}{|l|}{ Long-run } \\
\hline \multirow[t]{2}{*}{$g d p$} & $-0.038^{* * *}$ & 0.000 & $g d p_{t}^{+}$ & $-0.053 * * *$ & 0.000 \\
\hline & & & $g d p_{t}^{-}$ & $-0.081 * * *$ & 0.003 \\
\hline \multicolumn{6}{|l|}{ Short-run } \\
\hline$c$ & 1.209 & 0.123 & $c$ & $1.287 *$ & 0.098 \\
\hline$\Delta u n_{t-1}$ & $-0.338 * * *$ & 0.000 & $\Delta u n_{t-1}$ & $-0.225 * *$ & 0.049 \\
\hline$\Delta u n_{t-2}$ & $-0.319 * *$ & 0.011 & $\Delta u n_{t-2}$ & $-0.275^{* *}$ & 0.030 \\
\hline$\Delta u n_{t-3}$ & $-0.251 * * *$ & 0.000 & $\Delta u n_{t-3}$ & $-0.211 * * *$ & 0.000 \\
\hline$\Delta u n_{t-3}$ & 0.144 & 0.371 & $\Delta u n_{t-3}$ & 0.193 & 0.180 \\
\hline$\Delta g d p_{t}$ & -0.027 & 0.253 & $\Delta g d p_{t}^{+}$ & -0.016 & 0.579 \\
\hline$\Delta g d p_{t-1}$ & $-0.056 * * *$ & 0.031 & $\Delta g d p_{t}^{-}$ & 0.020 & 0.532 \\
\hline$E C_{t-1}$ & $-0.204 *$ & 0.090 & $E C_{t-1}$ & $-0.282 *$ & 0.077 \\
\hline
\end{tabular}

Note: $* * *, * *, *$ reject the null hypothesis at the $1 \%, 5 \%$ and $10 \%$.

Our findings can be linked to some existing empirical studies. Ball, Furceri, Leigh, and Lounganet (2019) applying symmetric Okun documented that Okun's law exists in Malaysia and the Philippines. The Okun's coefficient varies across the countries but the coefficient of Okun is higher for the Philippines as a less developed country. Kim, Park, and Jei (2015) who investigate the Okun's law in the East Asian countries including Singapore over the period 1986-2011 using EGARCH, found that asymmetric Okun's law exists in Singapore but the degree of Okun's coefficient is different over time due to industry structure. Another empirical study from Kim, Yoon, and Jei (2020) for the ASEAN-6 using time-series both GARCH and EGARCH indicated that asymmetric Okun's law is found in Malaysia and the Philippines because the contribution of Foreign Direct Investment (FDI) to domestic output is high and there is a coexisting between unskilled workers surplus and skilled workers shortage.

\section{Conclusion}

Our study investigates the symmetric and asymmetric responses of unemployment to output changes in the ASEAN-3. We employ the ARDL model, Nonlinear ARDL (NARDL), and the symmetric and asymmetric Pooled Mean Group (PMG) method. This study finds some interesting results regarding the unemployment-output tradeoff in the ASEAN-3. Based on the symmetric relationship, we document that Okun's law is found in all countries but the coefficient of Okun varies across countries depending on economic development condition. More interestingly, this study found that Okun's law is asymmetric in all cases. The economic downturn has a worse impact on unemployment than economic upturn which is related to the level of skilled labor in each country. Generally, using both symmetric and asymmetric panel PMG, we affirm that Okun's law exists for all countries but the economic downturn has a larger impact on the unemployment rate than the economic upturns in the ASEAN-3.

Some policy implications come up from these results. The Philippines could enhance employment absorption during an economic boom through upgrading labor skills to increasing value-added of agricultural and non-agricultural export products. Singapore, which heavily relies on foreign labor to support economic growth, could lessen more jobs losing during an economic recession by restructuring the labor market through limiting foreign labor. Lastly, expansionary fiscal policy through a tax cut and easy monetary policy through 
low interest rate are considerably important to mitigate unemployment during an economic downturn for all cases.

\section{Acknowledgement}

The author would like to thank the Center for Economic Studies, Department of Economics, Universitas Islam Indonesia, Yogyakarta, Indonesia for providing the fund under the Research Grant No.239/Dir.PPE/XI/2019.

\section{References}

Altissimo, F., \& Violante, G. L. (2001). The non-linear dynamics of output and unemployment in the U.S. Journal of Applied Econometrics, 16(4), 461-486. https://doi.org/10.1002/jae.599

An, Z., Ball, L., Jalles, J., \& Loungani, P. (2019). Do IMF forecasts respect Okun's law? Evidence for advanced and developing economies. International Journal of Forecasting, 35(3), 1131-1142. https://doi.org/10.1016/j.ijforecast.2019.03.001

Anderton, R., Aranki, T., Bonthuis, B., \& Jarvis, V. (2014). Disaggregating Okun's Law, Decomposing the Impact of the Expenditure Components of GDP on Euro Area Unemployment. Working Paper Series. ECB, 1747.

Andonova, D. U., \& Petrovska, M. (2019). Disaggregating Okun's Law: A Case-Study for Macedonia. Journal of Central Banking Theory and Practice, 8(1), 183-207. https://doi.org/10.2478/jcbtp-2019-0009

Attfield, C. L. F., \& Silverstone, B. (1998). Okun's law, cointegration and gap variables. Journal of Macroeconomics, 20(3), 625-637. https://doi.org/10.1016/S01640704(98)00076-7

Ball, L. (2017). Okun's Law: Fit at 50? Journal of Money, Credit and Banking, 49(7), 14131441.

Ball, L., Furceri, D., Leigh, D., \& Loungani, P. (2019). Does One Law Fit All? Cross-Country Evidence on Okun's Law. Open Economies Review, 30(5), 841-874. https://doi.org/10.1007/s11079-019-09549-3

Belaire-Franch, J., \& Peiró, A. (2014). Asymmetry in the relationship between unemployment and the business cycle. Empirical Economics, 48(2), 683-697. https://doi.org/10.1007/s00181-014-0803-0

Beyaert, A., \& García-Solanes, J. (2014). Output gap and non-linear economic convergence. $\begin{array}{llll}\text { Journal of } \quad \text { Policy } & \text { 36(1), }\end{array}$ https://doi.org/10.1016/j.jpolmod.2013.11.001

Cevik, E. I., Dibooglu, S., \& Barişik, S. (2013). Asymmetry in the unemployment-output relationship over the business cycle: Evidence from transition economies. Comparative Economic Studies, 55(4), 557-581. https://doi.org/10.1057/ces.2013.7

Christopoulus, D. K. (2004). The relationship between output and unemployment: Evidence from Greek regions. Papers in Regional Science, 83, 325-335. https://doi.org/10.1016/B0-12-369398-5/00365-0

Durech, R., Minea, A., Mustea, L., \& Slusna, L. (2014). Regional evidence on okun's law in czech republic and slovakia. Economic Modelling, 42, 57-65. https://doi.org/10.1016/j.econmod.2014.05.039

Gabrisch, H., \& Buscher, H. (2006). The relationship between unemployment and output in post-communist countries. Post-Communist Economies, 18(3), 261-276. https://doi.org/10.1080/14631370600881804 
Grant, A. L. (2018). The Great Recession and Okun's law. Economic Modelling, 69(August 2017), 291-300. https://doi.org/10.1016/j.econmod.2017.10.002

Hamada, \& Kurosaka. (1984). The Relationship Between Production and unemployment in Japan. European Economic Review, 25, 71-94.

Harris, R., \& Silverstone, B. (2001). Testing for asymmetry in Okun's law: a cross-country comparison. Economics Bulletin, 5(2), 1-13.

Im, K. S., Pesaran, M. H., \& Shin, Y. (2003). Testing for unit roots in heterogeneous panels. Journal of Econometrics, 115(1), 53-74. https://doi.org/10.1016/S03044076(03)00092-7

Kangasharju, A., Tavera, C., \& Nijkamp, P. (2012). Regional Growth and Unemployment:The Validity of Okun's Law for the finnish Regions. Spatial Economic Analysis, 7(3), 381-395. https://doi.org/10.1080/17421772.2012.694141

Kim, J., Yoon, J. C., \& Jei, S. Y. (2020). An empirical analysis of Okun's laws in ASEAN using time-varying parameter model. Physica A: Statistical Mechanics and Its Applications, 540, 123068. https://doi.org/10.1016/j.physa.2019.123068

Kim, M. J., Park, S. Y., \& Jei, S. Y. (2015). An empirical test for Okun's law using a smooth time-varying parameter approach: evidence from East Asian countries. Applied Economics Letters, 22(10), 788-795. https://doi.org/10.1080/13504851.2014.978068

Koutroulis, A., Panagopoulos, Y., \& Tsouma, E. (2016). Asymmetry in the response of unemployment to output changes in Greece: Evidence from hidden co-integration. Journal of Economic Asymmetries, 13, 81-88. https://doi.org/10.1016/j.jeca.2016.03.003

Lee, J. (2000). The robustness of Okun's law: Evidence from OECD countries. Journal of Macroeconomics, 22(2), 331-356. https://doi.org/10.1016/S0164-0704(00)00135-X

Levin, A., Lin, C., \& Chu, C. J. (2002). Unit root tests in panel data: asymptotic and ÿnitesample properties. Journal of Econometrics, 108, 1-24.

Marinkov, M., \& Geldenhuys, J. P. (2007). Cyclical unemployment and cyclical output: An estimation of Okun's coefficient for South Africa. South African Journal of Economics, 75(3), 373-390. https://doi.org/10.1111/j.1813-6982.2007.00134.x

Palombi, S., Perman, R., \& Tavéra, C. (2015). Regional growth and unemployment in the medium run: asymmetric cointegrated Okun's Law for UK regions. Applied Economics, 47(57), 6228-6238. https://doi.org/10.1080/00036846.2015.1068922

Pedroni, P. (1999). Critical Values for Cointegration Tests in Heterogeneous Panels with Multiple of Economics and Statistics, Vol. No. 0, pp. . Oxford Bulletin of Economics and Statistics, 61, 653-670.

Perman, R., \& Tavera, C. (2005). A cross-country analysis of the Okun's Law coefficient convergence in Europe. Applied Economics, 37(21), 2501-2513. https://doi.org/10.1080/00036840500366395

Pesaran, M. H., Pesaran, M. H., Shin, Y., \& Smith, R. P. (1999). Pooled Mean Group Estimation of Dynamic Heterogeneous Panels. Journal of the American Statistical Association, 94(446), 621-634. https://doi.org/10.1080/01621459.1999.10474156

Pesaran, M. H., Shin, Y., \& Smith, R. J. (2001). Bounds testing approaches to the analysis of level relationships. Journal of Applied Econometrics, 16(3), 289-326. https://doi.org/10.1002/jae.616

Pesaran, M. H., \& Smith, R. (1995). Econometrics Estimating long-run relationships from dynamic heterogeneous panels. Journal of Econometrics, 68, 79-113.

Shin, Y., Yu, B., \& Greenwood-nimmo, M. (2014). Modelling asymmetric cointegration and dynamic multipliers in a Nonlinear ARDL framework. In: Sickels, R., Horrace, W. (Eds.), Festschrift in Honor of Peter Schmidt: Econometric Methods and Applications. Springer, New York, 281-314. https://doi.org/10.1007/978-1-4899-8008-3 
Silvapulle, P., Moossa, I. A., \& Silvapulle, M. J. (2004). Asymmetry in Okun's law. Canadian Journal Of Economics, 37(2), 353-374.

Tang, B., \& Bethencourt, C. (2017). Asymmetric unemployment-output tradeoff in the Eurozone. Journal of Policy Modeling, 39(3), 461-481. https://doi.org/10.1016/j.jpolmod.2017.01.003

Virén, M. (2001). The Okun curve is non-linear. Economics Letters, 70(2), 253-257. https://doi.org/10.1016/S0165-1765(00)00370-0

Weber, C. E. (1997). The paper-bill spread and Blanchard's version of Okun's law. Applied Economics Letters, 4(7), 437-440. https://doi.org/10.1080/135048597355212 